\title{
The Development of Guided Inquiry-Based on Physics Modules At Static Fluid Material to Improve Critical Thinking Skills
}

\author{
Zekka Maulita Chrishar Putri ${ }^{1}$, Sarwanto $^{2}$, Harjana $^{3}$ \\ \{z.maulita@gmail.com¹, sarwanto@fkip.uns.ac.id ${ }^{2}$, harjana@staff.uns.ac.id ${ }^{3}$ \} \\ 1,2,3 Universitas Sebelas Maret, Surakarta Jawa Tengah, Indonesia
}

\begin{abstract}
Physics is a learning that contains facts and theoretical concepts that can be used to help improve students' critical thinking skills. Inquiry learning is learning that emphasizes the thinking process of students through certain stages so that students find themselves the concept of learning. Using inquiry learning strategies can produce meaningful knowledge so that knowledge is inherent in students' long-term memory. The application of inquiry in educational units requires adequate supporting teaching materials, but the availability of inquiry-based modules is still rare. The stages of learning with inquiry strategies are 1) orientation, 2) formulating problems, collecting hypotheses, 4) collecting data 5) testing hypotheses 6) conclusions. Guided inquiry will be presented in the form of modules, so that in the module there are elements namely student worksheets, and observation activities. With these elements encourage students to find concepts directly from experiments conducted by students. The application of guided inquiry-based modules in learning is expected to enable students to find concepts based on experience.
\end{abstract}

Keywords: Inquiry, modul, critical thinking

\section{Introduction}

The function of the national education system is to develop capabilities and shape the potential and dignified national civilization in the context of educating the life of the nation, aiming at developing the potential of students to become human beings who believe and be devoted to an almighty god, noble, knowledgeable, creative, capable , noble, independent and become democratic and responsible citizens. It is stated in law number 20 of 2003 concerning the national education system, article 1 number 1 states that education is a conscious and planned effort to create an atmosphere of learning and learning process so that students actively develop their potential to have religious spiritual strength, self-control, personality, intelligence, noble character, and skills needed by himself, society, nation and country.

The module is a component that has an important role in the learning process. Modules can help students in obtaining information about learning material. However, the development of modules needs to be adjusted to the students necessity. Physics subject is one part of natural science that is done to develop thinking skills in solving problems related to events around and can develop self-confidence skills.

Teaching materials used by both teachers and students do not provide activities that can give rise to students' critical thinking skills. Textbooks used by students sometimes do not bring up real applications. In addition, textbooks used by students in general directly provide 
material, without being started by problems that can make students think critically and motivate students to explore information on these problems.

According to Yusrizal (2016: 140), students still experience difficulties in understanding the concept of static fluid. Proven in several studies relating to misconceptions on Static Fluid material including Goszewski et al. (2012) and Wagner (2013), among others (1) the more fluid that is above a point, the greater the hydrostatic pressure experienced by that point (Loverude, et al., 2010; Besson, 2004; Goszewski, et al., 2012 ; Berek, 2016), (2) the buoyancy experienced by an object depends on the density of the fluid even though the object is equally floating in the various types of fluid (Loverude, et al., 2003), (3) the fluid pressure in the enclosed space is greater than the pressure in the open space even though the two vessels are interconnected (Goszewski, et al., 2012), (4) the amount of lift that occurs on objects is inversely proportional to the density of the liquid used (Utami, 2014). Therefore, static fluid material is still a misconception in students' understanding. Static fluid material has the characteristics of conceptual analysis that allows students to link the concepts of physics with natural phenomena, so students are expected to think and reason up to apply in everyday life. This student's misunderstanding of static fluid material is due to the lack of students' knowledge in understanding related physical phenomena. Problems that arise in the material hydrostatic pressure, Pascal's Law, and Archimedes's Law can be caused by various factors.

\section{Theoretical Basis}

\subsection{Module}

Surahman (2010) states that the module is the smallest learning program that can be studied by students individually (self instructional) after participants complete one unit in the next module, participants can step forward and learn the next module unit containing a description of the learning objectives, guide sheets instructor or instructor who explains efficient teaching methods, reading material for participants, answer key sheets on participant worksheets, and learning evaluation tools. So that we can understand that the module is one of the learning media in the form of an independent package book which includes a series of learning experiences that are planned and arranged systematically with the aim of helping students. While the main purpose of writing modules is to improve the efficiency and effectiveness of learning in schools, both time, funds, facilities, and energy to achieve learning goals that have been formulated and aspired (Daryanto, 2013: 34).

According to the Directorate of Vocational High School Education (in Module Compilation Engineering, 2008: 4), a module can be said to be good if it has the following characteristics:

a. Self Instructional namely through this module students are able to learn independently, not dependent on other parties.

b. Self Contained, that is, all learning material from one competency unit or sub-competency learned is contained in one module as a whole.

c. Stand Alone is a module that is developed that does not depend on the media or does not have to be used together with other media.

d. Adaptive, the module can adjust the development of science and technology, and is easy to use (can be used anywhere and anytime).

e. User Friendly, the module should be friendly with the user.

Module basically has several elements. MONE (2008) mentions elements contained in a module including: 
a. Teaching purpose

Teaching objectives are formulated explicitly and specifically.

b. Instructions for teachers

Teacher instructions contain an explanation of how learning can be carried out by the teacher effectively and efficiently.

c. Student Activity Sheet

This sheet contains subject matter that must be mastered by students.

d. Student worksheet

This student worksheet is organized so that students are actively involved in the learning process.

e. The Answer Key to Student Work

The module is better accompanied by a worksheet key so students can correct or evaluate the results of their work and stay active learning.

f. Test Sheet (Evaluation)

The success or failure of the teaching and learning process is actually determined by the results of student work on the evaluation sheet.

g. Key Test Sheet (Evaluation)

The key to this test sheet is to find out how far the learning outcomes have been obtained, then correct and improve it.

\subsection{Guided Inquiry Learning}

According to Sanjaya (2008: 195) inquiry method is one way of learning by emphasizing the process of thinking critically and analytically to find and find answers to a problem in question to search and investigate systematically, critically, logically, analytically, so students can formulate his own findings. So it can be concluded that inquiry is a learning process that is emphasized on the process of finding problems carried out by students by carrying out several stages of activities to be carried out by students that will help in understanding the concept of material in teaching materials.

There are several characteristics of guided inquiry that need attention:

a. Students develop thinking skills through specific observations to make inferences or generalizations.

b. The goal is to study the process of observing an event or object and then arrange the appropriate generalization.

c. The teacher controls certain parts of the learning such as events, data, materials and acts as a class leader.

d. Each student tries to build a meaningful pattern based on observations in the classroom.

e. The class is expected to function as a learning laboratory.

f. Usually a certain number of generalizations will be obtained from students.

g. The teacher motivates all students to communicate the results of their generalizations so that they can be used by all students.

The steps of learning with the inquiry method strategy are (Sanjaya, 2008: 202-205):

a. Orientation

The orientation step is to foster a responsive learning atmosphere or climate.

b. Formulate the Problem

This step leads students to a problem that contains a puzzle. 
c. Formulate Hypothesis

The hypothesis is a temporary answer to a problem that is being studied.

d. Collecting data

Collecting data is the activity of gathering information needed to test the proposed hypothesis.

e. Test the Hypothesis

Hypothesis testing is the process of determining the answers that are considered acceptable in accordance with the data or information obtained based on data collection.

f. Formulating conclusions

Formulating conclusions is the process of describing findings obtained based on the results of hypothesis testing.

The benefits of guided inquiry learning in this study are to practice courage, communicate, and try to get their own knowledge to solve problems faced by students.

\subsection{Critical thinking skill}

Silverman and Smith (2002) define critical thinking as thinking that has a purpose, makes sense, and is goal-oriented as well as the ability to analyze information and ideas carefully and logically from various perspectives (in Tawil and Liliasari, 2013: 7 ). So it can be concluded that critical thinking describes a process of thinking that is "active" or not just "passive" just accepting the ideas of others.

The step of critical thinking according to Arthur L. Costa cit. Hendra Surya (2012: 179) critical thinking steps can be grouped into 3 namely:

a. Recognizing problems, assessing information, and solving problems or drawing conclusions.

b. Assess relevant information.

c. Troubleshooting or drawing conclusions

Indicators of critical thinking skills are divided into 5 groups (Ennis in Tawil and Lilliasari, 2013: 9) as presented in Table 1.

Table 1. Processes and Operational Words for Critical Thinking

\begin{tabular}{|l|l|}
\hline \multicolumn{1}{|c|}{$\begin{array}{c}\text { Indikator } \\
\text { Indicator }\end{array}$} & \multicolumn{1}{|c|}{$\begin{array}{c}\text { Kata-Kata Operasional } \\
\text { Operational Words }\end{array}$} \\
\hline $\begin{array}{l}\text { Provide a simple } \\
\text { explanation } \\
\text { clarification })\end{array}$ & $\begin{array}{l}\text { Analyze statements, } \\
\text { submit and answer } \\
\text { classification questions. }\end{array}$ \\
\hline Build basic skills & $\begin{array}{l}\text { Considering that the } \\
\text { source is trustworthy or } \\
\text { not, researching and } \\
\text { evaluating an observation } \\
\text { report. }\end{array}$ \\
\hline Make an inference & $\begin{array}{l}\text { Deduction activities or } \\
\text { consider the results of } \\
\text { education, induce or }\end{array}$ \\
\hline
\end{tabular}




\begin{tabular}{|l|l|}
\hline (inferring) & $\begin{array}{l}\text { consider the results of } \\
\text { induction, and make and } \\
\text { assess valuable } \\
\text { valuations. }\end{array}$ \\
\hline $\begin{array}{l}\text { Provide further } \\
\text { explanation } \\
\text { (advanced } \\
\text { clarification) }\end{array}$ & $\begin{array}{l}\text { Define the term, assess } \\
\text { the definition and } \\
\text { identify assumptions. }\end{array}$ \\
\hline Set strategy and tactics & $\begin{array}{l}\text { Deciding actions to } \\
\text { interact with other } \\
\text { people. }\end{array}$ \\
\hline
\end{tabular}

Maryam (2008) suggests that critical thinking activities can be done by looking at the appearance of some behaviors during the critical thinking process that takes place. Someone's critical thinking behavior can be seen from several aspects, namely:

a. Relevance (relevance), the relevance of the statement stated.

b. Important (importance), assessing the importance or not the issue or main points expressed.

c. Novelty (novelty), the contents of the mind both in bringing new ideas or information and in the attitude of accepting the existence of new ideas of others.

d. Material from outside (outside material), using his own experience or materials received from lectures (reference).

e. Classifying what is not clear (ambiguity clarified), seeking explanation or further information if there is something unclear.

f. Linking ideas (linkin ideas), always linking facts, ideas or views and looking for new data from information that has been collected.

g. Decide (justification), provide evidence or examples of a solution or conclusion that was taken.

The benefits of critical thinking skills in this study can be determined that critical thinking skills basically focus on a statement of the problem and find the value of clarity based on the data collected. The data must have logical reasons and accurate evidence to get a solution or decision from the statement stated.

\section{Conclusion}

The development of guided inquiry-based modules can resolve the problem of students' poor critical thinking skills. The application of the guided inquiry-based module in learning, it is hoped students can find concepts based on experience, while the teacher as a facilitator explains the learning objectives through the module. It is hoped that through guided inquirybased modules can improve students' critical thinking skills. 


\section{References}

Daryanto. Inovasi Pembelajaran Efektif. Bandung: Yrma Widya. (2013).

Depdiknas. (2008). Panduan Pengembangan Bahan Ajar. Jakarta: Depdiknas.

Depdiknas. (2008). Pedoman Penulisan Modul. Jakarta:Direktorat Pendidikan Menengah

Kejuruan.

Goszewski, M., Moyer, A., Bazan, Z., \& Wagner, D. J. (2012). Exploring student difficulties with pressure in a fluid. Physics Eeducation Research Conference, vol. 1513(1), pp 154-157.

Surya, H. (2011). Strategi Jitu Mencapai Kesuksesan Belajar. Jakarta:PT Elex Media Komputindo

Maryam, S. dkk. (2008). Buku ajar berpikir kritis dalam proses keperawatan. Jakarta: Buku Kedokteran EGC.

Loverude, M. E., Heron, P. R. L., \& Kautz, C. H. (2010). Identifying and addressing student difficulties with hydrostatic pressure, American Journal of Physics, vol. 78(1), pp 7585.

Maryam, S. dkk. (2008). Buku ajar berpikir kritis dalam proses keperawatan. Jakarta: Buku Kedokteran EGC.

Parmin \& Peniati, E. (2012). Pengembangan Modul Mata Kuliah Strategi Belajar Mengajar IPA Berbasis Hasil Penelitian Pembelajaran. Jurnal Pendidikan IPA Indonesia. (JPII) 1 (1), 8-15.

Prarstowo, A. (2011). Metode Penelitian Kualitatif Dalam Perspektif Rancangan Penelitian. Jogjakarta: Ar-Ruzz Media.

Sanjaya, Wina. (2008). Perencanaan dan desain sistem pembelajaran. Jakarta: Kencana Prenada Media Group.

Tawil, M., \& Liliasari. (2013). Berpikir Kompleks dan Implementasinya dalam Pembelajaran IPA. Makasar: Badan Penerbit UNM.

Utami, R., Djudin, D. \& Arsyid, S. B. (2014). Remediasi Miskonsepsi Pada Fluida Statis Melalui Model Pembelajaran TGT Berbantuan Mind Mapping Di SMA. Jurnal Pendidikan dan Pembelajaran, (Online), 3(12): 1-12.

Yusrizal. 2016. Analysis of Difficulty Level of Physics Examination's Questions. Jurnal Pendidikan IPA Indonesia. (JPII) 5 (1), 140-149. 